\title{
LET'S TALK ABOUT ROYALTIES: \\ THE CONTINUED UNCERTAINTY SURROUNDING THE Creation AND Legal Status OF THE OVERriding Royalty
}

\author{
DAVID LEGEYT, ASHLEY WELDON, \\ NATASHA WOOD, AND BRENDAN DOWNEY*
}

\begin{abstract}
The oil and gas and mining industries developed the practice of creating royalties that would run with the land. This led to the Supreme Court of Canada's decision in Bank of Montreal v. Dynex Petroleum Ltd. Despite the decision in Dynex recognizing a new property right and changing the common law, the law remained unsettled until the Third Eye Capital Corporation v. Ressources Dianor Inc./Dianor Resources Inc. and Manitok Energy Inc (Re) decisions apparently simplified the concept of royalties as property interests. In this article, the authors explore the overriding royalty, its common law evolution, the uncertainties surrounding its proper legal characterization, the implications of such legal uncertainty, and the shift the Dianor and Manitok decisions represent, while considering the nature of the interests that royalties represent, the manner in which industry has attempted to protect those interests, and the efficacy of such attempts.
\end{abstract}

\section{TABLE OF CONTENTS}

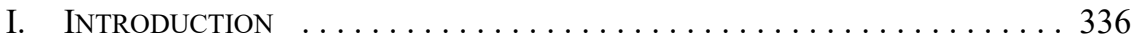

II. ROYALTIES AND THE IMPORTANCE OF AN “INTEREST IN LAND” . . . . . 337

A. WHAT is a Royalty? ....................... 337

B. Royalties IN THE INSOLVENCY CONTEXT $\ldots \ldots \ldots \ldots \ldots . \ldots 338$

III. THE History OF Royalties AS INTERESTS IN LAND IN CANADA $\ldots \ldots . .340$

A. OVERRIDING ROYALTIES AS INTERESTS IN LAND:

IT IS THEORETICALLY POSSIBLE . . . . . . . . . . . . . 341

B. The Keyes Dissent: A Harbinger of Future Changes? . . . . . 341

C. The Common Law Continues to Evolve:

THE EMPHASIS REMAINS ON THE ENTIRE AgREEMENT $\ldots \ldots \ldots . .342$

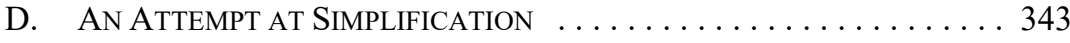

E. Is This MORE SubSTANTIVE APPROACH

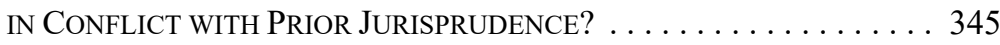

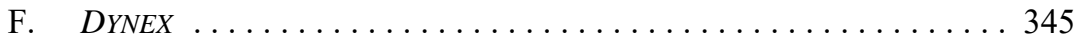

G. Post-DyneX Treatment of Royalties $\ldots \ldots \ldots \ldots \ldots \ldots . \ldots 347$

IV. Dianor AND MANitoK: A New Path Forward? . . . . . . . . . . . . . 349

A. DIANOR ................................. 349

B. A Return to Basics: The ONTARIo COURT OF APPEAL's RECALIBRATED APPROACH TO RoyALties $\ldots \ldots \ldots \ldots \ldots \ldots$

C. MANITOK: AN APPARENT ENDORSEMENT

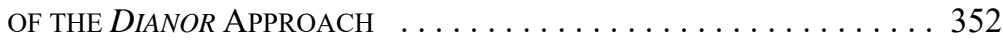

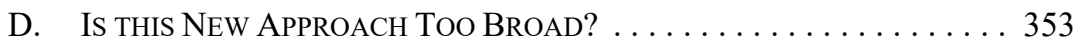

V. The Unanswered, LoOMing Question In Dianor $\ldots \ldots \ldots \ldots \ldots 354$

David LeGeyt and Ashley Weldon are partners at Burnet, Duckworth \& Palmer LLP in the Restructuring and Insolvency and Energy practice groups, respectively; Natasha Wood is an associate at Burnet, Duckworth \& Palmer LLP in both the Restructuring and Insolvency and Energy practice groups; and Brendan Downey is an associate at Burnet, Duckworth \& Palmer LLP in the Energy practice group. 


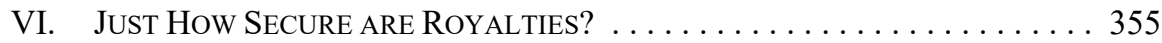

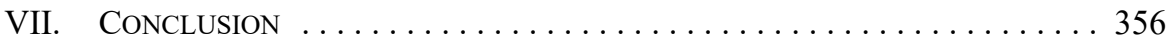

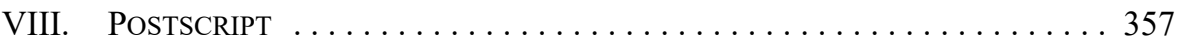

\section{INTRODUCTION}

Since the Leduc No. 1 oil well was drilled in 1947, the petroleum and natural gas industry has grown to become a cornerstone of the Alberta economy and a major industry for the Canadian economy. The oil and gas industry is active in 12 of 13 Canadian provinces and territories, ${ }^{1}$ and Canada is the fifth-largest producer of natural gas and the sixth-largest producer of crude oil globally. ${ }^{2}$

Royalties are central to the financing, development, and operation of oil and gas projects and other mineable resources in Canada. Traditionally, royalties allowed resource owners to participate in and reap the benefit of production from their properties, and also to raise funds to finance exploration and production activities. In Alberta alone, royalty revenues from natural gas, conventional oil, and oil sands production were over $\$ 500$ million, $\$ 700$ million, and $\$ 1.4$ billion, respectively, for 2016-2017. In 2013-2014, these revenues were even higher, totalling $\$ 1.1, \$ 2.5$, and $\$ 5.2$ billion, respectively. ${ }^{3}$ Given the significant value associated with these royalties, ensuring the viability of such interests is paramount to industry participants. In response to this need, the industry developed a practice whereby parties would attempt to create royalties that would "run with the land"4 with the intention that the resulting royalty survives for so long as the underlying interest from which it was granted survives, binding successors in interest to the underlying leasehold or freehold estate. The benefit of this designation is clear: a royalty that runs with the land can provide its owner with certainty as to their rights and interest, regardless of what happens to the original grantor. In fact, it was this very industry practice that led to the Supreme Court of Canada's groundbreaking decision in Bank of Montreal v. Dynex Resources Ltd., which recognized that mineral lessees could carve out real property interests in the form of royalties. ${ }^{5}$ Dynex was revolutionary in recognizing a new property right and changing the common law.

Almost two decades after Dynex, there are now public and private companies with oil and gas royalties as the principal or sole focus of their business. For example, PrairieSky Royalty Ltd. (PrairieSky) and Freehold Royalties Ltd. (Freehold Royalties) are two public companies that focus primarily on obtaining royalty interests and payments. PrairieSky's 2017 royalty revenues alone topped $\$ 265$ million, ${ }^{6}$ and, as of 1 August 2018 , it had a market capitalization

\footnotetext{
1 Canadian Association of Petroleum Producers, "Industry Across Canada," online: <capp.ca/canadianoil-and-gas/industry-across-canada>.

Canadian Association of Petroleum Producers, "Canada’s Energy Resources," online: <capp.ca/ canadian-oil-and-natural-gas/canadas-petroleum-resources>.

Government of Alberta, "Historical Royalty Revenue Data," online: <alberta.ca/historical-royaltyrevenue-data.aspx $>$.

Strathcona (County) v Half Moon Lake Resort Ltd, 2013 ABQB 405 at para 50.

2002 SCC 7 [Dynex SCC], aff'g 1999 ABCA 363 [Dynex CA].

PrairieSky Royalty Ltd, "Consolidated Financial Statements for the Year Ended December 31, 2017" (26 February 2018), online: <prairiesky.com/files/galleries/2017_Annual_PSK_Financial_Statements_ Sedar.pdf $>$.
} 
of $\$ 5.8$ billion. ${ }^{7}$ Similarly, Freehold Royalties's 2017 royalty revenues reached $\$ 133$ million, ${ }^{8}$ and its market capitalization is $\$ 1.4$ billion. $^{9}$ In recent years, royalty interests that are interests in land have been created by working interest owners and then sold to third parties for values of up to $\$ 250$ million. ${ }^{10}$ These examples clearly illustrate the magnitude and importance of royalties in the oil and gas industry and the need for commercial certainty in dealing with these valuable interests.

Despite guidance from the Supreme Court of Canada and the obvious commercial importance of royalties, the law in this area remains unsettled. Recently, however, the Ontario Court of Appeal's decision in Third Eye Capital Corporation v. Ressources Dianor Inc/Dianor Resources Inc. ${ }^{11}$ and the Alberta Court of Queen's Bench's decision in Manitok Energy Inc $(R e)^{12}$ have apparently simplified the understanding of royalties as property interests. In this article, we explore the overriding royalty, its common law evolution, the uncertainties surrounding its proper legal characterization, the implications of such legal uncertainty, and the shift that the Dianor and Manitok decisions represent. Throughout our discussion, we will consider the nature of the interests that royalties represent, the manner in which industry has attempted to protect those interests, and the efficacy of such attempts.

\section{ROYALTIES AND THE IMPORTANCE OF AN "INTEREST IN LAND"}

\section{A. What is a Royalty?}

Royalties come in many forms in the natural resources sector. For example, a particular set of mineral rights may be encumbered by a lessor royalty, a net profits interest, a gross overriding royalty (GORR), or a combination of these. Each of these is a royalty, but each operates in a different manner. A lessor royalty is reserved by the lessor from the minerals leased to the lessee, and paid by the lessee as a fraction of production to the lessor. ${ }^{13}$ The lessor royalty is, in effect, a payment for the right to extract mineral or petroleum resources, and may be payable to a private freehold mineral owner pursuant to a lease or, if the Crown is the mineral owner, the government in accordance with a legislated royalty scheme. A net profits interest is payable by the working interest owners, and is often a percentage of the net

S\&P Capital IQ, "PrairieSky Royalty Ltd.: Public Company Profile,” online: <capitaliq.com/CIQDot Net/company.aspx? companyId=262030211>.

8 Freehold Royalties Ltd, "High Risk Low Performer: Annual Report 2017" (8 March 2018), online: $<$ freeholdroyalties.com/sites/default/files/uploads/reports-filings/fru_annual_report 2017 final.pdfs. S\&P Capital IQ, supra note 7.

PrairieSky Royalty Ltd, "PrairieSky Announces Royalty Acquisition and Concurrent Bought Deal Equity Financing," Globenewswire (14 December 2016), online: <globenewswire.com/news-release/ 2016/12/14/1323979/0/en/PrairieSky-Announces-Royalty-Acquisition-and-Concurrent-Bought-DealEquity-Financing.html>; Athabasca Oil Corporation, "Athabasca Oil Corporation Announces a \$129 Million Contingent Bitumen Royalty and Repayment of US\$221 Million Term Loan," Globenewswire (20 June 2016), online: <globenewswire.com/news-release/2016/06/20/975948/0/en/Athabasca-OilCorporation-Announces-a-129-Million-Contingent-Bitumen-Royalty-and-Repayment-of-US-221Million-Term-Loan.html>; BlackPearl Resources Inc, "BlackPearl Announces the Sale of a Royalty Interest on Its Onion Lake Property for \$55 Million," Globenewswire (1 December 2016), online: $<$ globenewswire.com/news-release/2016/12/01/1299856/0/en/BlackPearl-Announces-the-Sale-of-aRoyalty-Interest-on-Its-Onion-Lake-Property-for-55-Million.html>.

2018 ONCA 253 [Dianor CA].

2018 ABQB 488 [Manitok].

Dynex CA, supra note 5 at para 30. 
proceeds of production. ${ }^{14}$ Generally, a GORR signals a percentage ownership in production or production revenues before the costs of production are deducted (though such deductions are subject to negotiation). GORRs are paid to the GORR owner by the grantor, which may be a current or former lessee or one of potentially many working interest partners.

Depending on the negotiated terms, a royalty may be payable in kind (by a share of the physical product produced) or payable in money (based on the price received) and calculable at any point from the wellhead to the point of sale. How the royalty is described in the royalty agreement will determine what sort of royalty it is. To that end, it is up to the parties to determine whether a royalty will be an interest in land or not, and to give effect to such intention. If the royalty is not an interest in land, it is merely executory and only exists as between the parties to the contract that created the royalty. If the royalty is an interest in land, however, it will attach to the underlying leasehold or freehold interest from which it was created, binding successors in interest and securing the interest of the royalty holder. Owners of a royalty expressed to be an interest in land are afforded the ability to register a caveat on the subject land title, thereby giving notice to potential purchasers and protecting the royalty against third parties and successors in interest. ${ }^{15}$

As the Alberta Court of Queen's Bench has surmised, royalties are granted for a wide variety of reasons each and every day in the oil and gas industry. ${ }^{16}$ Commonly, a lessee will farmout certain lands to a company with the capital and expertise to drill a well in exchange for a working interest subject to a GORR. This royalty structure ensures the lessee can retain an interest in and benefit from the lands it has acquired rights to, despite the fact that it was not equipped to conduct the drilling operations itself. GORRs are also granted as remuneration for geological expertise or obtaining a particular lease.

In our experience, a new royalty mechanism and practice has developed over the past two decades in which industry participants manufacture a royalty to sell in exchange for capital investment. These royalties typically take the form of a GORR over the grantor's working interest and have become an important component of the financing structure in oil and gas development. Given the risks inherent in upstream resource development, the investing party will seek to protect its interest to the greatest extent possible, generally by ensuring the agreement characterizes the GORR as an interest in land.

\section{B. ROYALTIES IN THE INSOLVENCY CONTEXT}

The characterization of a royalty becomes a crucial issue in the event of a royalty grantor's insolvency. Whether or not the royalty runs with the land may have a dramatic impact on the economics of the estate. In an insolvency proceeding, the question becomes whether the receiver or trustee must attempt to sell the underlying mineral interest subject to the royalty

14 Schlumberger, Oilfield Glossary, sub verbo "net profits interest,” online: < glossary.oilfield.slb.com/ Terms/n/net_profits_interest.aspx $>$; Dynex CA, supra note 5 at para 32.

15 Note that the current law in Alberta is unclear as to the proper forum for registration in circumstances where the overriding royalty interest is granted by the lessee of Crown-owned mines and minerals (as opposed to freehold). Section 202(a) of the Land Titles Act, RSA 2000, c L-4, prohibits registration of a caveat or encumbrance affecting Crown mineral interests. The Mines and Minerals Act, RSA 2000, c M-17, provides for a limited exception applicable generally only to financial institutions.

16 Bank of Montreal v Dynex Petroleum Ltd (1995), [1996] 6 WWR 461 at para 84 (Alta QB). 
or whether it can rely on the court's power to vest property in a purchaser "free and clear" of the encumbrances of the debtor. This "interest in land" issue is directly related to the vesting issue, and is of the utmost importance to the parties. As discussed herein, these issues have recently collided in Dianor, and remain before the Ontario Court of Appeal and, potentially, the Supreme Court of Canada. ${ }^{17}$

Whether a royalty is an interest in land will impact insolvency proceedings generally, and, more specifically, will impact: (1) the solicitation process by the court officer or debtor, (2) potential purchasers, (3) the purchase price for the assets, (4) the recovery for creditors, and (5) the royalty holder. These impacts have been particularly pronounced throughout the most recent downturn experienced in the Canadian natural resources sector.

Oil and gas and mining industry insolvencies are already complex given the nature of the assets, the business, and the current regulatory environment. In normal course dealings between solvent parties, if a particular royalty is an interest in land, it is an incident of the underlying estate and binds the purchaser of such estate. Conversely, if the royalty is only executory and the agreement is not assigned to the purchaser, the vendor retains the payment obligation (notwithstanding that it no longer owns the interest on which the royalty is payable), or, at the very least, is liable under the contract that created the royalty. In both cases, the royalty holder has legal recourse to enforce the payment of the royalty, though the creation of an interest in land provides greater certainty. In an insolvency, however, the receiver, bankruptcy trustee, or debtor in possession can disclaim executory contracts, leaving the contractual royalty owner with only an unsecured claim against the estate. For example, a British Columbia court recently concluded that a particular GORR was a mere contractual royalty and the assets in a restructuring could be sold and vested in the purchaser free and clear of the royalty agreement. ${ }^{18}$ This determination allowed the debtor in possession to terminate the royalty agreement to enhance the prospects of restructuring. ${ }^{19}$ Had the Court concluded that the royalty was an interest in land, it would have survived the insolvency and the payment obligation would have bound the purchaser. It is therefore clear why the characterization of the royalty is of critical importance to the royalty holder: an interest in land will always protect its right to payment.

A justice of the Ontario Superior Court of Justice further complicated matters in the trial decision in Dianor, commenting in obiter that there was "no reason in logic" why the Court would not have the jurisdiction to disclaim a royalty regardless of whether "the royalty rights were or were not an interest in land." ${ }^{20}$ These comments raised eyebrows in both the natural resources and insolvency industries as they effectively dismissed the express policy reasons underlying the Supreme Court's determination that overriding royalties can be interests in land. As discussed in detail below, the Dianor decision was overturned on appeal, but the

On 21 June 2018, the Supreme Court of Canada granted an order extending the time for serving and filing an application for leave to appeal to 30 days following the Court of Appeal for Ontario fully disposing of the matter. The Court of Appeal has yet to release its decision on this matter. For further details, please see Supreme Court of Canada, "Docket 38106: Third Eye Capital Corporation v. Ressources Dianor Inc./Dianor Resources Inc., et al.” (4 May 2018), online: <scc-csc.ca/case-dossier/ info/dock-regi-eng.aspx? cas $=38106>$.

Walter Energy Canada Holdings, Inc (Re), 2016 BCSC 1746 at para 72 [Re Walter].

Ibid; Companies’ Creditors Arrangement Act, RSC 1985, c C-36, s 32.

Third Eye Capital Corp v Dianor Resources Inc, 2016 ONSC 6086 at para 40 [Dianor SCJ], rev'd Dianor CA, supra note 11. 
question of whether a debtor's property can be sold free and clear of a royalty interest found to run with the land remains before the courts. It is the position of the authors that royalties that are interests in land are effectively ownership rights in the property, and the protections afforded by such status mean that it cannot be vested off like an encumbrance held by a creditor.

\section{The History OF RoyAlties AS INTERESTS IN LAND IN CANADA}

Historically, the common law was not entirely clear on whether a mineral lessee - a holder of a profit à prendre ${ }^{21}$ in Crown or freehold lands - could create a royalty that was an interest in the land. It was not clear whether producer-granted royalties could be interests in land. In the face of this uncertainty, Canadian courts have deliberated the legal nature of these overriding royalties for at least 50 years, fashioning a complicated basis on which GORRs could be interests in land. In short, if the parties to an overriding royalty endowed it with a number of ostensibly superfluous incidents of an interest in land, the court would recognize it as such. On paper, this was a triumph of form over substance. Industry participants had no choice but to create instruments called royalties that were not in fact royalties, laden as they were with rights no one ever intended to exercise. ${ }^{22}$ Rather than recognizing that GORRs could themselves be interests in land, Canadian courts would recognize interests in land that happened to operate like royalties.

We note that this formalistic approach likely arose from the jurisprudential uncertainty underlying the early royalty decisions: can a producer carve a royalty interest out of their mineral lease such that it runs with the land? The Supreme Court of Canada's decision in Dynex attempted to provide a definitive answer to that question. There were no "convincing policy reasons for maintaining the common law prohibition on the creation of an interest in land from an incorporeal hereditament." ${ }^{, 3}$ The customs and commercial realities in the oil and gas and mining industries warranted a shift in the law to recognize overriding royalty interests as interests in land where: (1) the parties' intention to create an interest in land was sufficiently clear, and (2) the underlying interest from which the royalty was carved could support it.

Dynex represented an abrupt change in the common law, creating a novel property interest on the strength of widespread industry practice. ${ }^{24}$ Unfortunately, the ad hoc nature of the preexisting body of case law made it difficult to fix the parameters of this two-step test. PostDynex, the question confronted by Canadian lawyers and courts was whether Dynex affirmed the prior case law, or whether it exhausted its relevance by applying an old test to a newly recognized property interest. Until recently, the apparent consensus was that Dynex affirmed these principles. However, Dianor and Manitok suggest that this view is incorrect, advocating a simplified approach that keeps with the spirit of the Dynex test by focusing primarily on the intentions of the parties.

See e.g. Berkheiser v Berkheiser, [1957] SCR 387, in which the Supreme Court determined that oil and gas leases are profits à prendre-a form of incorporeal hereditament.

Dianor CA, supra note 11 at para 71 .

Dynex SCC, supra note 5 at para 18 .

Ibid at paras 17-20. 


\section{A. OVERRIDING ROYALTIES AS INTERESTS IN LAND: It IS Theoretically Possible}

St. Lawrence Petroleum Ltd. v. Bailey Selburn Oil \& Gas Ltd. was one of the first Canadian cases to confront the question of whether a share in the net proceeds of production could be an interest in land. ${ }^{25}$ In this case, the Supreme Court ultimately determined the royalty at issue was not an interest in land. However, the judgment of Justice Martland is notable for two reasons: (1) it opened up the common law to the possibility that overriding royalties could be interests in land if such an intention was expressed in "plain and unmistakable words," ${ }^{26}$ and (2) his reasoning appears to consider the entirety of the agreement, an element that came to inform much of the later jurisprudence. ${ }^{27}$

In identifying the intentions of the parties, the Supreme Court held that a royalty agreement in which the grantor remained in complete control of the royalty lands and the grantee's sole entitlement was a share in the net proceeds of production is inconsistent with an interest in land. ${ }^{28}$ This finding arguably established the first "indicium" of a royalty interest in the land - control over the lands. In considering this matter, courts would ask, "Does the grantee have a right to enter and win the minerals for themselves? Is the royalty an entitlement to a percentage of the 'monies to be derived from the sale of production, ${ }^{29}$ or is it an interest in the mineral in the ground?"

Later courts came to view this distinction as an important factor to consider when asked to determine whether a royalty was an interest in land. Six years later, for example, an Alberta appellate court applied St. Lawrence Petroleum to hold that a royalty calculable and payable on produced hydrocarbons was a contractual right and not an interest in land. ${ }^{30}$ More broadly, the concepts and questions articulated in St. Lawrence Petroleum crept into subsequent courts' decision-making, influencing the development of the law of royalties in unpredictable ways.

\section{B. The Keyes Dissent: A Harbinger of Future Changes?}

Justice Laskin further advanced the law of royalties with his dissent in Saskatchewan Minerals $v$. Keyes. ${ }^{31}$ At issue in the Keyes case was the respondent's entitlement to a royalty payable on anhydrous salt produced from two leases. The respondent could only succeed in his application if the royalty was an interest in land. ${ }^{32}$

As identified in Justice Laskin's reasons for dissent, three clauses were of central import to his interpretation of the royalty agreement: (1) a clause assigning all of the respondent's right, title, and interest in the underlying leasehold and minerals; (2) a reservation of a

[1963] SCR 482 at 485, 487 [St Lawrence Petroleum].

Ibid at 490 .

Ibid at $488-89$

Ibid at 489 .

Ibid at 490 .

Emerald Resources Ltd v Sterling Oil Properties Management Ltd (1969), 3 DLR (3d) 630 (Alta SC

(AD)) at 640-42.

[1972] SCR 703 [Keyes].

Ibid at 706-707, 712 . 
royalty carved out of that underlying leasehold interest; and (3) a clause providing that the royalty agreement would enure to the benefit of and bind the parties, their heirs, administrators, successors, and assigns. ${ }^{33}$ Absent these clauses, there were no clear expressions of intent.

In his analysis, Justice Laskin appears to have been of the view that a royalty expressed as a right to payment on the production of some mineral can be an interest in land, even if the right to payment does not arise until after the mineral has been severed and reduced to a chattel. This conclusion flowed from his opinion that royalties are analogous to rents, which were historically treated as interests in land:

This is not to say that every reservation or grant of a royalty creates an interest in land. The words in which it is couched may show that only a contractual right to money or other benefit is prescribed. However, if the analogy is to rent, then the fact that the royalty is fixed and calculable as a money payment based on production or as a share of production, or of production and sale, cannot alone be enough to establish it as merely a contractual interest. ${ }^{34}$

In three sentences, Justice Laskin deftly affirmed the possibility that a royalty can be an interest in land, that the words evidencing an intention to create an interest in land must be construed against the terms of the agreement as a whole, and rejected Justice Martland's position on behalf of the majority in both Keyes and St. Lawrence Petroleum that a royalty payable on the net proceeds of production could not be an interest in land. ${ }^{35}$ Finally, the Keyes dissent suggests the formulation of the language that actually creates the interest in land is an important consideration in identifying its character, particularly where it "accords with language that has been held sufficient for the creation of an interest in land." 36

Multiple courts later found Justice Laskin's dissenting reasons to be persuasive. ${ }^{37}$ His contribution to the development of this area of law is therefore instructive. Not only did his judgment lend further support to the idea that a grantor's intentions can only be determined in the context of the entire agreement, but he refused to blindly follow the Supreme Court's previous technical rejection of a royalty payable on production. In addition, he affirmed a new indicium for courts to look to in ascertaining whether a royalty is an interest in land: the presence of granting language.

\section{The Common Law Continues to Evolve: The EMPHASIS REMAINS ON THE ENTIRE AgREEMENT}

In Bensette v. Reece, the Saskatchewan Court of Appeal began its analysis of a disputed royalty with the observation that a royalty's "meaning must be deduced from the circumstances surrounding its use. ${ }^{" 38}$ Considered in the context of St. Lawrence Petroleum

Scurry-Rainbow Oil Ltd v Galloway Estate, [1993] 4 WWR 454 (Alta QB) [Scurry-Rainbow], aff'd 1994 ABCA 313; Canco Oil \& Gas Ltd v Saskatchewan, [1991] 4 WWR 316 (Sask QB) [Canco]. (1973), 34 DLR (3d) 723 at 725 (Sask CA) [Reece]. 
and Keyes, this suggests that the target of the inquiry remains the parties' intentions as revealed by the entire agreement, and, arguably, the circumstances surrounding its formation. Having established its starting point, the Reece Court relied on the granting language in the royalty agreement to support its determination that the disputed royalty was an interest in land, holding, just as Justice Laskin had written in Keyes, that the language "doth give, grant, bargain, sell, assign and transfer ... a ... royalty in all the ... minerals ... which may be found in, under or upon the said lands" displayed an intention to create an interest in the land. ${ }^{39}$

Beyond the granting language, the Court sought to ascertain the intentions of the parties by inquiring into the language "couching" the royalty. Specifically, the Court was concerned with the meaning of the phrase, "a 'royalty' in "the minerals.", 40 Perhaps logically, the Court held that a royalty in the minerals is an interest that inheres in the minerals; a royalty on the minerals, on the other hand, would have indicated the parties merely intended to create a commission or some other executory interest (the "in/on" distinction). ${ }^{41}$ This distinction persisted in the common law for some time.

In Vanguard Petroleums Ltd. v. Vermont Oil \& Gas Ltd., the Alberta Supreme Court substantially agreed with the reasoning in Reece, concluding that courts must consider the facts of the parties' relationship and "examine the language under particular sets of circumstances to determine the nature of [the] royalty." 42 The Court also found the "in/on" distinction persuasive; ${ }^{43}$ however, it declined to accept Justice Laskin's characterization of a royalty as something akin to rent. Unlike a royalty, rent is a payment in consideration of or as compensation for the use and occupation of another's property. ${ }^{44}$ In this way, it is intrinsically tied to the underlying property right. By contrast, a GORR in the oil and gas and mining sectors is a covenant to pay a third party a percentage share upon the production of the subject substance or mineral.

\section{An Attempt at Simplification}

As the number of royalty cases before the courts grew, the number of considerations that courts felt obliged to consider grew in step. The Guar. Trust Co. v. Hetherington decision is a good example of this complexity. ${ }^{45}$ In Hetherington, the Court surveyed the existing case law on royalties, developing the following list of factors to consider when attempting to characterize a royalty:

1. the intention of the parties; ${ }^{46}$

2. the presence of granting language; ${ }^{47}$

Ibid at 726 .

Ibid [emphasis added].

Ibid.

(1977), 72 DLR (3d) 734 (Alta SC) at 740-41 [Vanguard].

Ibid at 740 .

Ibid at $740-41$.

[1987] 3 WWR 316 (Alta QB) [Hetherington], aff'd [1989] 5 WWR 340 (Alta CA).

Hetherington, ibid at 339-41, 344-45.

Ibid at 340-41. 
3. the manner in which the interest is described; ${ }^{48}$

4. the words in which the royalty is couched (the "in/on" distinction), ${ }^{49}$ and

5. the operation of the entire agreement. ${ }^{50}$

Arguably, the latter four indicia flow from the first - the parties' intentions. By considering these specific factors, courts could seek to ascertain the intention motivating the creation of the royalty, even if that intention was not expressly stated in the agreement. Though not discussed in Hetherington, an additional factor from St. Lawrence Petroleum should be added to this list:

6. the degree of control the grantor retains over the royalty lands.

In an apparent effort to simplify this inquiry, the Alberta Court of Queen's Bench in Vandergrift $v$. Coseka Resources Ltd. proposed a two-step test to apply to royalty agreements. ${ }^{51}$ It was this test that the Supreme Court ultimately endorsed in Dynex. ${ }^{52}$ In its analysis, however, the Court in Vandergrift continued to follow the lead of the earlier decisions, examining the agreement as a whole and relying on the "in/on" distinction to determine that the disputed royalty was not an interest in land.

Thus, by 1993, there were at least six indicia a court could refer to in determining whether a royalty was an interest in land. The purpose of this approach was to identify the intentions of the parties where they were not clearly stated, and to ensure that the agreement actually gave effect to those intentions. But there was a problem: how were the various factors to be weighed against each other? Moreover, how should a court weigh these factors against each other when the parties that attempted to create the interest in the first place may have done so before the indicia the courts developed had found their way into the common law?

In Scurry-Rainbow, Justice Hunt narrowed this list, rejecting the "in/on" distinction relied upon in Vanguard and Vandergrift on the basis that fine technical distinctions such as this are not reflective of commercial reality. ${ }^{53}$ Rather than relying on overly technical and legalistic modes of reasoning, Justice Hunt instead urged courts to direct their analysis to the "substance of the transaction," focusing the inquiry on identifying what the parties were actually trying to achieve. ${ }^{54}$ Following Scurry-Rainbow, it appears the common law had jettisoned one technical indicia of an interest in land and redirected its focus to what the parties actually intended, rather than what the terms of the agreement accomplished in a vacuum..$^{55}$

Ibid at $342,344-45$.

Ibid at 342-43.

Ibid at 346 .

(1989), 95 AR 372 at para 29 (QB) [Vandergrift].

Supra note 5 at para 22.

Scurry-Rainbow, supra note 37 at para 44.

Ibid at para 45.

While the royalties at issue in Scurry-Rainbow were Gross Royalty Trust Agreements, Justice Hunt's discussion of the law on royalties has been more recently cited in relation to gross overriding royalties as well. See Dynex CA, supra note 5; Dynex SCC, supra note 5; Re Walter, supra note 18; Dianor CA, supra note 11; Manitok, supra note 12. 


\section{E. Is This More SubStantive APPROACH in CONFLICT WITH PRIOR JURISPRUdenCE?}

Justice Hunt's focus on actual intention appears to confirm an earlier decision from the Saskatchewan Court of Queen's Bench, Canco, which asked if a royalty agreement should be interpreted in light of the intentions of the parties, or whether it should be construed more conservatively, giving effect only to what the terms of the agreement actually accomplish in light of the various factors courts should consider. ${ }^{56}$ In other words, should a court look only at what the mechanics of the agreement achieve, or should it also consider what the parties intended to create?

The answer to this question appears to be both. The most important questions in characterizing royalty interests are: (1) whether the grantor is capable of granting the interest, (2) whether the grantor intended to grant an interest in the land, and (3) whether the grantor accomplished its intention. ${ }^{57}$ Of these three questions, the Court's comments suggest the second question - the intentions of the parties - is the main point of inquiry. The mere fact that the grantor failed to use the precise wording previous courts have considered essential to the creation of interests in land cannot detract from a clearly manifested intention to create that interest. ${ }^{58}$

But a consistent theme of Canadian royalty cases has been that it is not enough to simply call something an interest in land. It has to actually be an interest in land. Importantly, it appears the Canco Court was alive to the fact that the expressed intentions of the parties could provide important context to the effect of the royalty agreement. As long as a royalty grantor has an interest in the underlying estate, its intention to alienate part of it in favour of another should be given effect to where possible. In Canco, for example, the agreement expressly stated that the parties intended that the royalty would run with the land. ${ }^{59}$ This clearly expressed intention likely allowed the Court to overlook other deficiencies in the rest of the agreement, or construe them in the context of the commercial circumstances and the parties' intentions. While it is unlikely that a clearly stated intention would have been determinative at the time, the Court's reasoning in Canco is consistent with the earlier tests, while also affording Justice Hunt the space to redirect the inquiry to the substance of the parties' intentions in Scurry-Rainbow.

\section{F. DYNEX}

Conducting a thorough assessment of the law of royalties in Dynex, the Alberta Court of Appeal acknowledged that the pivotal question a court must ask in determining whether a royalty runs with the land is whether the parties intended to convey such an interest. ${ }^{60}$ Importantly, however, the Court held that simply stating the interest is an interest in land is

Ibid.

Ibid at para 9. See also John Bishop Ballem, The Oil and Gas Lease in Canada, 4th ed (Toronto: University of Toronto Press, 2008) at 183.

Dynex CA, supra note 5 at paras 32-33, citing St Lawrence Petroleum, supra note 25. 
insufficient; ${ }^{61}$ rather, the interest can only be properly characterized by "interpreting the agreement as a whole and within its context. ${ }^{" 62}$

As developed in Canco and Scurry-Rainbow, the proper approach is to examine the parties' intentions from the agreement as a whole, along with a proper consideration of the surrounding circumstances. ${ }^{63}$ That said, this approach should not be overly literal, particularly if it leads to an unrealistic result that the parties would not themselves have contemplated at the time of contract. ${ }^{64}$ Accordingly, the Court concluded that parties can create royalties that are interests in land if their intentions to do so are clear. ${ }^{65}$ In ascertaining their intentions, the following indicia are relevant:

1. [t]he underlying interest is an interest in land (corporeal or incorporeal);

2. [t]he intentions of the parties, as evidenced by the language of the grant and any admissible evidence of the surrounding circumstances or behaviour, indicate that it was understood that an interest in land was created/conveyed;

3. $[\mathrm{t}]$ he interest is capable of lasting for the duration of the underlying estate. ${ }^{66}$

Other possible signposts include:

4. a reservation of an interest in the petroleum substances by the farmor/royalty holder in the working interest to be earned by the farmee/royalty grantor;

5. whether the farmee/royalty grantor is an agent of the farmor/grantee for the farmor's/grantee's share of petroleum production;

6. the existence of remedies against the interest of the farmee/royalty grantor through a proprietary remedy such as a lien. ${ }^{67}$

On appeal to the Supreme Court, Justice Major agreed with the appellate decision "[f]or substantially the same reasons." ${ }^{68}$ However, instead of adopting the indicia suggested by the Court of Appeal (as set out above), he cited the "succinctly stated" two-part Vandergrift test:

1. the language used in describing the interest is sufficiently precise to show that the parties intended the royalty to be a grant of an interest in land, rather than a contractual right to a portion of the oil and gas substances recovered from the land; and

2. the interest, out of which the royalty is carved, is itself an interest in land. ${ }^{69}$

Dynex CA, ibid at para 73 .

Ibid at para 33 .

Ibid at para 73 .

Ibid at paras 68-69, citing Scurry-Rainbow, supra note 37 at para 86.

Ibid at para 82 .

Ibid at para 84 .

Ibid.

Dynex SCC, supra note 5 at para 6.

Ibid at para 22 . 
It is interesting to note that, as originally set out in Vandergrift, the Dynex test closely, but not exactly, tracks the first two indicia contained in the Court of Appeal test. It is arguable that the Supreme Court's reference to a similar but different articulation of the test set out by the lower court suggests a desire to depart from that aspect of its decision - the accompanying indicia, in particular - emphasizing the clear intentions of the parties. In doing so, the Supreme Court appears to have collapsed the inquiry to focusing almost exclusively on the intentions of the parties as disclosed by the language of the agreement. A minor caveat on this point: despite adopting the approach taken in Vandergrift, it is important to note that the Supreme Court did not endorse Justice Virtue's analysis, nor did it endorse the specific factors relied on in the Vandergrift analysis. ${ }^{70}$

When the Dynex dispute was re-heard at trial, Justice Hawco referred to the indicia set out by the Court of Appeal, ${ }^{71}$ but only applied one of them in his reasons. He expressly referred to the facts that: (1) the royalty was expressed to be a percentage of the proceeds of sale of petroleum substances produced from the lands, ${ }^{72}$ (2) unlike in Canco, there was no clear expression of intent; ${ }^{73}$ and (3) the royalty holder had failed to register a caveat to protect the interest. ${ }^{74}$ Despite relying on the Dynex test and referring to the indicia in the Court of Appeal decision, it is notable that Justice Hawco relied on altogether different factors in determining that the royalty was not an interest in land.

The decision in the trial re-hearing highlights the difficulties that courts have had in applying the Dynex test, and calls into question the steps that a court should follow in conducting the inquiry. Should a court rely solely on the intentions of the parties? Should it consider the mechanics of the agreement as set out in previous case law? Should it do both? It is unfortunate that the first post-Dynex case to interpret a royalty agreement was not entirely clear in its approach. Similarly, the decisions that followed are equally inconsistent.

\section{G. Post-Dynex Treatment of Royalties}

The foregoing review of the pre-Dynex royalty case law illustrates the confused evolution this area of law has experienced. Not only was it unclear whether the common law would even recognize a real property right arising from an incorporeal hereditament, but those courts that elected to consider the matter in spite of this uncertainty adopted idiosyncratic approaches. The indicia that courts developed and applied was in a constant state of flux: it was common for judges to consider new factors or ignore factors previously relied upon. Meanwhile, commercial lawyers assisting parties in drafting royalty agreements were left to discern which language and provisions would best establish an interest in land as determined by the shifting common law.

Dianor CA, supra note 11 at para 73.

Bank of Montreal v Dynex Petroleum Ltd, 2003 ABQB 243 at para 39.

Ibid at para 52.

Ibid at para 53.

Ibid at para 55. 
Though courts had previously recognized that GORRs could be interests in land, it was not until Dynex that Canadian law affirmatively recognized the validity of this proposition. In recognizing the viability of creating such interests, the Alberta Court of Appeal and Supreme Court of Canada both responded, in large part, to the needs of industry. Because the investment structure in the oil and gas and mining industries relied so heavily on the creation of royalties that could "run with the land" regardless of which company owned the relevant mineral lease, the courts understood the need to protect them from commercial uncertainty. ${ }^{75}$

Given the sui generis nature of the property right and the clear policy motivations underlying both the Court of Appeal and Supreme Court judgments, it is certainly arguable that the Supreme Court of Canada sought to reorient the inquiry to focus primarily on the intentions of the parties. If the underlying hereditament is capable of supporting a royalty interest in the land and the parties intend to create one, why is that intention not enough?

As history shows, courts did not respond to Dynex this way. Instead, they continued to apply the pre-Dynex indicia. As was the case before Dynex, industry participants in the oil and gas and mining sectors continued to grapple with the uncertainty created by the inconsistent development and application of the pre-Dynex indicia. Indeed, royalty agreements that complied with the indicia in existence at the time they were drafted may not have been compliant with the law at the time they were later litigated. One example of this is the James H Meek $v$. San Juan Resources Inc. royalty dispute. ${ }^{76}$

The overriding royalty at issue in San Juan was created in 1952 - one decade before Justice Martland suggested that overriding royalties on production could be interests in land if the parties so intended. However, it did not appear before a court for another five decades. In the intervening period, the law of royalties underwent enormous change. It could not have been possible for the original drafters of the agreement to anticipate what a court would find relevant some 50 years later.

Tasked with determining whether the royalty was an interest in land, Justice LoVecchio attempted to discern the original parties' intentions. To that end, he determined it was not enough that the San Juan royalty contained the appropriate granting language. ${ }^{77}$ Whatever degree of intention the granting language illustrated was outweighed by the facts that: (1) the royalty was a payment obligation "payable out of production," reserve a right to take the royalty in kind - their interest in the royalty was passive ${ }^{79}$ and (3) the royalty holders did not attempt to register a caveat against title. ${ }^{80}$

It is unknown whether a statement that the parties intended the royalty to be an interest in land would have bolstered the applicants' position in light of the Dynex decision. What is clear, however, is that relying on an evolving list of indicia to determine whether royalty

Dynex CA, supra note 5 at paras 39-40, 45 .

2003 ABQB 1053 [San Juan], rev'd on other grounds, 2005 ABCA 448.

San Juan, ibid at paras 36-37.

Ibid at paras 37-38.

Ibid at para 39.

Ibid at para 43. 
agreements drafted years earlier were interests in land creates a great deal of commercial uncertainty. Not only that, but such uncertainty seems contrary to the express policy reasons that motivated the Dynex decisions in the first place.

Viewed along this historical continuum, the law of royalties remains unclear. In 2018, the Ontario and Alberta courts delivered a sequence of decisions suggesting that the post-Dynex courts have missed the mark in their deference to the pre-Dynex case law. Consistent with the Dynex test, the principal point of inquiry ought to be the expressly stated intentions of the parties. As well, the Ontario case of Dianor has given rise to an incredibly troubling question: even if a royalty is a valid interest in land, does a superior court judge retain the inherent jurisdiction to transfer the underlying property "free and clear" of the royalty in the course of insolvency proceedings? If the Ontario Court of Appeal ultimately decides that courts do have this jurisdiction, the policy and commercial realities motivating the Dynex decisions will be completely undermined.

\section{Dianor ANd Manitok: A NeW Path ForWARd?}

\section{A. DIANOR}

In 2016, Justice Newbould released his decision in Dianor ${ }^{81}$ - a decision that immediately attracted the interest of Canadian insolvency, energy, and mining lawyers. After Dianor Resources Inc. (Dianor) entered insolvency proceedings in August 2015, its receiver sought an order approving the sale of certain assets to Third Eye Capital Corporation (Third Eye) free and clear of all encumbrances. A third party, 2350614 Ontario Inc. (235), did not oppose the sale, but argued that the transfer was subject to royalty rights that attached to the land.

Though the decision does not cite the legal authority for the position, Third Eye argued that the royalty could be cancelled through a vesting order and the payment of fair compensation to $235 .^{82}$ Justice Newbould's analysis began with an acknowledgment of the Dynex test and a consideration of the language that created 235 's gross overriding royalties.

The royalty was payable in respect of diamonds and all other metals and minerals produced from the lands. ${ }^{83}$ Importantly, the diamond royalty was calculated in respect of the average appraised value of all diamonds recovered or produced from the lands; the metals and minerals royalty was calculated in respect of Dianor's realized gross revenue. ${ }^{84}$ In other words, the royalty applied to the products after they had been either recovered, or recovered and sold, respectively. However, similar to the royalty agreement in Canco, the royalty agreement in Dianor contained a clause expressly stating that the parties intended the royalty to be an interest in land, running with the royalty lands and binding all successor parties. ${ }^{85}$ Justice Newbould's view, however, was that this expression of intent was just that - an expression of intent. The agreement failed to give effect to that intention and actually convey

Dianor SCJ, supra note 20.

Ibid at para 15 .

Ibid at para 18 .

Ibid at paras 18-20.

Ibid at para 22. 
an interest in land. ${ }^{86}$ In other words, the key to identifying its true character was to determine whether the agreement carried out the intent, not whether the intent was clearly expressed.

Relying on cases that looked to the nature of royalty-granting covenants, Justice Newbould identified two factors that rendered the royalty a contractual interest, not an interest in land:

1. the agreement failed to extend to 235 a right to enter and "enjoy" the lands; ${ }^{87}$ and

2. the description of the royalty was couched in language suggesting it applied either to minerals produced from the lands or revenues derived therefrom. ${ }^{88}$

The Court also relied on case law that appears to have found the "in/on" distinction persuasive. ${ }^{89}$ Given his finding that the royalty was not an interest in land, Justice Newbould concluded that he had the jurisdiction to grant the proposed vesting order, selling the lands to Third Eye free and clear of 235's royalty. This decision appears to have been consistent with the approach Canadian courts had historically taken to the royalty question, though it could be said that the reasoning adopted a fairly conservative approach to identifying and weighing the parties' intentions. Problematically, Justice Newbould then declared in obiter that he could "see no reason in logic ... why the jurisdiction would not be the same whether the royalty rights were or were not an interest in land." ${ }^{90}$ Respectfully, such a fundamental change in the perceived boundaries of a court's jurisdiction must be grounded in law, not logic.

\section{B. A Return to Basics: The Ontario Court OF ApPeal's RECALIBRATED APPROACH TO ROYALTIES}

With the exception of his comments as to the court's inherent jurisdiction to vest off interests in land, Justice Newbould's decision was not entirely surprising: it was a technical application of fairly well-established case law. On appeal, however, the Ontario Court of Appeal took a different approach, signalling a preference for a more straightforward and practical analysis. As the Court recognized, the uncertainty surrounding the nature of gross overriding royalties prior to Dynex was due to the fact that the common law viewed the right to take resources from another's land to be an interest in land, but it did not extend the same consideration to the right to a payment of profits. ${ }^{91}$ The Supreme Court of Canada's decision in Dynex officially scrapped this old rule of the common law, creating a sui generis property interest to keep the law in step with modern commercial practices. ${ }^{92}$

Ibid at para 23 .

Ibid at para 24. The authors note that Justice Newbould appears to have viewed the right to "enter and enjoy" as functionally equivalent to certain civil law rights to enter, use, profit from, and dispose of the lands (usus, fructus, abusus). These rights are much more closely related to the bundle of rights that a working interest partner would require to benefit from its interest, not a royalty holder.

Ibid at paras 25-26.

Ibid at para 25, citing St Andrew Goldfields Ltd v Newmont Canada Ltd, [2009] OJ No 3266 (QL) at paras 101-103 (Sup Ct J), aff'd 2011 ONCA 377.

Dianor SCJ, ibid at para 40.

Dianor CA, supra note 11 at para 36.

Ibid at paras 38-42; Dynex SCC, supra note 5 at paras 17-20; Dynex CA, supra note 5 at paras 29, 34-45. 
Because commercial practices in the oil and gas and mining industries evolved under the assumption that GORRs could be interests in land, the Court of Appeal in Dianor noted that the Supreme Court of Canada in Dynex elected to change the common law solely on policy grounds to "permit a royalty interest, including a [GORR], to become an interest in land, consistent with industry practice." 93 The Court of Appeal in Dianor noted that it was to accommodate these practices that the Supreme Court "quite deliberately changed the common law," expressly predicating the creation of the interest on the parties' intentions. ${ }^{94}$

In arriving at its decision, the Court of Appeal in Dianor CA appears to have been heavily persuaded by the fact that: (1) the Dynex Court of Appeal decision responded to industry practice and the intentions underlying that practice, and (2) the Supreme Court of Canada endorsed that approach. The implication is that, as expressed in Dianor, a court must "examine the parties' intentions from the agreement as a whole, along with the surrounding circumstances, as opposed to searching for some magic words." $" 95$ This approach, however, should be tempered by Justice Major's approval of Justice Laskin's comments in Keyes: "[T]he intentions of the parties judged by the language creating the royalty would determine whether the parties intended to create an interest in land or to create contractual rights only." 96 The Ontario Court of Appeal's decision in Dianor indicates that this was the Supreme Court's ultimate holding in Dynex. ${ }^{97}$

With respect to 235 's royalty, the Court applied the Dynex test to conclude that it was an interest in land: the royalty was itself carved out of an interest in land and the parties expressly stated in plain language that they intended the royalty to be an interest in land. Confirming this intention was the fact that the royalty holder subsequently registered its interest on title. ${ }^{98}$ The Court's decision to focus its inquiry on the express intentions of the parties is made clear at paragraph 65 of the decision:

The contractual terms are not necessarily determinative of whether an interest in land was intended; the language does not require magic words to demonstrate the parties' intention. However, these words were present in the Agreements. In my view, the appellant's [GORRs] constitute interests in land that run with the land and are capable of binding the claims in the hands of a purchaser. ${ }^{99}$

While not decisive, the fact that language clearly setting out the express intentions of the parties is present in the agreement is highly persuasive as to the manner in which the interest should be construed. To further substantiate its position, the Court reconsidered Justice Newbould's reasons with an emphasis on the express intentions of the parties. In failing to interpret the agreement with that perspective in mind, the Court concluded that Justice Newbould erred in treating the fact that 235 did not retain a right to enter the lands and explore for minerals as anathema to an interest in land. ${ }^{100}$ In addition, the fact that the royalty

Dianor CA, ibid at para 44.

Ibid at para 43 .

Ibid at para 54, citing Dynex CA, supra note 5 at para 73 .

Dynex SCC, supra note 5 at para 12 .

Dianor CA, supra note 11 at para 55, citing Dynex SCC, supra note 5 at para 12 .

Dianor CA, ibid at paras 62-64.

Ibid at para 65 .

Ibid at para 67. 
was a right to share in the proceeds of production did not mean that it could be an interest in land. ${ }^{101}$

The purpose of a royalty that runs with the land is to allow a passive interest holder to protect its economic interests. Demanding that the royalty holder retain a right to enter the lands before its royalty will be an interest in land fails to align with the intentions of the parties to a royalty agreement. ${ }^{102} \mathrm{With}$ respect to the character of the royalty, the Court of Appeal simply relied on Laskin J's judgment in Keyes to conclude that the mere fact that a royalty is to be calculated with respect to production cannot, by itself, defeat the clear intentions of the parties. ${ }^{103}$

\section{MANITOK: AN APPARENT ENDORSEMENT OF THE DIANOR APPROACH}

Less than two months after the Ontario Court of Appeal delivered its judgment in Dianor, Justice Horner of the Alberta Court of Queen's Bench heard submissions concerning a similar application in Manitok. ${ }^{104}$ In this case, an insolvent energy company, Manitok Energy Inc. (Manitok), informed its receiver that it did not believe a producing royalty held by Freehold Royalties Partnership (Freehold) was an interest in land. After reviewing the royalty agreements, the receiver revoked Freehold's take-in-kind rights, which Freehold had been exercising for six months prior to the receivership order. Freehold contested Manitok's position, applying to the Court for a declaration that the royalty was an interest in land, and that it was entitled to take-in-kind all oil volumes corresponding to its royalty interest.

The royalty itself was created and defined across two related agreements - a Production Volume Acquisition Agreement (the Acquisition Agreement) and a Production Volume Royalty Agreement (the Royalty Agreement). Both Agreements expressly stated that the royalty was intended to be an interest in land. ${ }^{105}$ Moreover, Schedule B of the Royalty Agreement contained abbreviated granting language, but reiterated that the royalty was an interest in land that would "run with the land" in respect of all oil volumes "within, upon or under the [lands]."106 The Agreements clearly set out that Manitok could not contest the character of the royalty and that Freehold retained a first-priority right to receive the royalty, ${ }^{107}$ as well as a right to take the royalty in kind. ${ }^{108}$

Notwithstanding the stated intentions of the parties and the presence of some language to suggest the royalty was an interest in land, a number of provisions appear to have run contrary to that intention. The scheme of the Royalty Agreement routinely defined the royalty in terms of produced volumes, and was expressed to be "in respect of" produced oil volumes, rather than an interest in the oil volumes in situ. ${ }^{109}$ The royalty was not fixed, but

$\begin{array}{ll}101 & \text { Ibid at para 67. } \\ 102 & \text { Ibid at paras 71-72. } \\ 103 & \text { Ibid at paras 76-77. } \\ 104 & \text { Supra note 12. } \\ 105 & \text { Ibid at paras 5-6. } \\ 106 & \text { Ibid at para 7. } \\ 107 & \text { Ibid at para 7. } \\ 108 & \text { Ibid at para 8. } \\ 109 & \text { Ibid. }\end{array}$


set to decline over time. ${ }^{110}$ This could suggest that it was not an immutable interest in the minerals themselves, but a contractual right to share in the profits of production with reference to a sliding scale. Finally, and perhaps most problematic, was the fact that Manitok could assign the royalty lands on notice to Freehold, but was obliged to offer a substitute property in which Freehold's royalty interest would continue. ${ }^{111}$ How could it be said that the interest was in the land if the land itself could change?

Freehold argued that the Dynex test had been misconstrued by Canadian courts over the past 15 years. Relying on the two-part Dynex test, Freehold's position was that it is enough that those two requirements are satisfied. If the parties clearly state their intention to create an interest in land out of a profit à prendre, the courts should recognize it. As a result, there is no need to go beyond the clearly stated intentions of the parties and inquire into the indicia set out by the pre-Dynex courts.

Without so stating, Justice Horner appears to have accepted this argument ${ }^{112}$ particularly in light of the Dianor decision:

\footnotetext{
I am satisfied, therefore, that a royalty in respect of produced substances, representing a fixed quantity of production per day, may constitute an interest in land if the parties' intention to make it so is sufficiently clear. I am also satisfied that a royalty may constitute an interest in land despite the absence of, or significant limitations on, a right of entry.
}

The other factors cited ... are also not sufficient to defeat what appears to have been the clear intention of Freehold and Manitok to create an interest in land. ${ }^{113}$

If we consider the Manitok decision in the context of Dianor, so long as it is clear that the parties intended to create an interest in the land, courts should defer to that intention. This can generally be accomplished through the use of an express acknowledgment that the parties intend to create an interest in land. It is only where the agreement is otherwise silent that the pre-Dynex indicia are necessary to identify the parties' intention.

\section{Is This NeW APProACH TOO BRoAd?}

Is this recent shift in the way that courts weigh the clearly expressed intentions of the parties a cause for concern? Not necessarily.

It seems counterintuitive to adopt the view that simply calling something an interest in land makes it an interest in land. One cannot point to a dog, call it a cat, and have it be so. In a sense then, this new approach opens the law of royalties up to abuse. However, overriding royalties as interests in land are unique. The Supreme Court clearly departed from common law principles of property law to recognize that they can be interests in land where the parties so intend. It is therefore arguable that the pre-Dynex indicia are not necessary features of royalties that are also interests in land. They are incidents of ownership that courts 
historically relied on to work around the common law prohibition on creating an interest in land out of an incorporeal hereditament. Overriding royalties that incorporate all of the indicia are not royalties at all: they are working interest rights that are accompanied by a percentage payment on production.

We recognize that an overly broad approach gives rise to certain concerns. That said, viewed as the product of an organic and constantly evolving legal process, there are strong reasons to believe that the courts in Dianor and Manitok got it right. The clearly stated intentions of the parties should be guiding and, if not determinative, at least highly persuasive.

\section{The UnANSWERED, LoOMING QUESTION IN DianoR}

Though Manitok was appealed to the Court of Appeal of Alberta by the receiver, the appeal has now been abandoned. Therefore, Manitok is the most recent Alberta pronouncement on these issues. However, the "royalty question" remains alive in the courts, and will remain so until the issues discussed herein are again addressed by either the Supreme Court of Canada or other appellate courts. There is potential for this to occur soon.

Dianor has been appealed to the Supreme Court of Canada; however, the leave application submissions are on hold pending the parties returning to the Ontario Court of Appeal and making further arguments on the contentious issue of the Court's ability to convey the underlying mineral interest free and clear of royalties irrespective of whether they are interests in land. The Ontario Court of Appeal indicated that this question was not adequately addressed in the facta or oral argument. Due to this, the Court directed further submissions on issues "of considerable importance to the insolvency practice." 114 Any natural resources lawyer or industry participant would assert that this issue is certainly one of considerable importance for their practice and business as well.

It is clear from the decision of the Court of Appeal (and on a plain reading) that the particular provisions of the Courts of Justice Act ${ }^{115}$ and the Bankruptcy and Insolvency Act ${ }^{116}$ raised in respect of the vesting off issue "do not expressly authorize a court to take real property out of the hands of a third party." 117 If a 3 percent GORR that is an interest in land is truly to be considered an "ownership" interest in the minerals in situ, then the debtor in possession, or the receiver stepping into the shoes of the debtor, should not be able to sell a 100 percent interest in the property free and clear of the GORR. Such a sale would be contrary to the principle of nemo dat quod non habet, meaning "no one can give that which he does not have." 118 Vesting off an interest in land of this nature would be a form of expropriation not provided for in either current insolvency legislation or the common law. However, despite authorities that bar a court from vesting off proprietary interests, the Court

\footnotetext{
114 Dianor CA, supra note 11 at para 13.

115 Courts of Justice Act, RSO 1990, c C.43, ss 100-101.

116 Bankruptcy and Insolvency Act, RSC 1985, c B-3, s 243.

117 Dianor CA, supra note 11 at para 107.

118 WestlawNext Canada, Canadian Abridgment Words \& Phrases, sub verbo "nemo dat quod non habet," online: <nextcanada.westlaw.com/Document/I52c5ee08253b12f2e0440003ba0d6c6d/View/FullText. html>, citing Barbaree v Bilo (1991), 126 AR 121 at para 12 (QB).
} 
of Appeal considered whether there are situations that may warrant such action and requested additional arguments from the parties on the following question:

Whether and under what circumstances and limitations ... a Superior Court judge has jurisdiction to extinguish a third party's interest in land using a vesting order, under s. 100 of the CJA and s. 243 of the BIA, where s. $65.13(7)$ of the BIA; s. 36(6) of the CCAA; ss. 66(1.1) and 84.1 of the BIA; or s. 11.3 of the CCAA do not apply? ${ }^{119}$

The comeback hearing took place in September $2018 ;{ }^{120}$ however, the Court has yet to release its decision, leaving insolvency and natural resources practitioners in suspense. Commercial lawyers are left to draft royalty agreements designed to protect their clients' interests without certainty as to the true state of the law. Insolvency practitioners are left to continue managing the estates of insolvent natural resources entities without clear common law direction as to what they can and cannot do. Interestingly, we note that since the Ontario Court of Appeal released its decision in Dianor, some recent Ontario decisions have already cited it for the proposition that an interest in land cannot be vested off the underlying mineral interest in an insolvency process. ${ }^{121}$

\section{Just How Secure Are Royalties?}

Despite the authors' view that Canadian courts lack the jurisdiction to wipe an underlying mineral interest clean of any pre-existing royalty interests in the land, such royalties are not entirely secure - and never have been. To begin, the royalty will only survive for so long as the underlying interest survives. While freehold lessor royalties are likely secure in this respect (the fee interest lasts into perpetuity), freehold GORRs can terminate if the underlying lease terminates. This puts the GORR-holder in a precarious position: the continued existence of their royalty interest is entirely dependent on the actions of the grantor or their successors in interest. If the grantor fails to produce in accordance with the terms of the lease (or improperly shuts in production), the GORR might terminate. Similarly, if the GORR is granted out of a Crown lease, it is important to keep in mind that, if the lease terminates (or is cancelled or surrendered), the underlying interest reverts back to the Crown free and clear of all pre-existing encumbrances. ${ }^{122}$ Again, notwithstanding the nature of the royalty, the GORR-holder is left in a precarious position and may lose their royalty interest through no fault of their own. Contractual provisions can provide some protection for royalty holders, such as agreeing that, notwithstanding the surrender or expiry of a lease, the royalty lands will remain subject to the royalty if the grantor or its affiliates re-acquire the royalty lands within a set period of time. However, the fate of the royalty is ultimately tied to the providence of the underlying interest.

Dianor CA, supra note 11 at para 121.

Ontario Courts, "Court of Appeal for Ontario: Monthly Case List" (last visited 14 August 2018), online: $<$ ontariocourts.ca/coa/en/caselist/monthlylist.htm>.

American Iron v 1340923 Ontario, 2018 ONSC 2810 at para 25; Krates v Crate, 2018 ONSC 2399 at para 23.

Mines and Minerals Act, supra note 15, s 32(1). 
The fact that GORRs that are interests in land can terminate notwithstanding their proper creation takes on even greater significance in the insolvency context. Because GORRs are encumbrances that diminish the value of the interest to which they attach, the desirability of the underlying leasehold interest will vary with prevailing market conditions. Thus, if the grantor of a GORR enters insolvency or bankruptcy proceedings, their receiver or trustee may not be able to sell the encumbered interest. In these circumstances, otherwise viable royalty generating wells can end up in the Orphan Well Fund, in part because the attached royalty is an obligation that purchasers were not willing to assume. This is an unfortunate consequence of the "royalty as interest in land" characterization and may motivate collaborative and other negotiated solutions among receivers or trustees, royalty holders, and prospective purchasers.

As a consequence of the current economic climate, royalty interests are no longer a passive investment. GORR holders should keep a close eye on their royalty grantors and successors in interest. Where formal insolvency proceedings are initiated, GORR holders should ensure that a representative is added to the service list and remains apprised of developments in the sales process and the licensed insolvency professional's management of the estate. Active participation in the insolvency process is important for all GORR holders regardless of whether their royalties can be characterized as interests in land or not. While an interest in land is afforded more protections than a contractual interest, the viability of such an interest is still at risk if the underlying leasehold estate is jeopardized, the possibility of which increases during insolvencies.

\section{ConClusion}

A close review of the Canadian jurisprudence on the nature of royalty interests and the threshold for a finding of an interest in land reveals that the case law is rife with inconsistencies and nuances that have led to an unclear understanding and inconsistent application of the Dynex test. What is clear, in an otherwise confusing area of the law, is the dire need for the Supreme Court of Canada to revisit its comments in Dynex and clarify its position definitively. Absent clarification, the commercial certainty that industry participants and insolvency practitioners seek will remain elusive. However, it is the authors' view that Dianor and Manitok signal a sensible path forward and, should the Supreme Court ultimately deny leave to appeal, represent a point from which the common law can evolve in a manner that enhances commercial certainty, reduces unnecessary disputes, and better captures the Supreme Court of Canada's intent in Dynex.

With respect to the outstanding vesting off issue raised in Dianor, the scope of the Court's equitable jurisdiction is a matter of primary importance in the insolvency context and also demands clarification. Royalties that are interests in land do not enjoy absolute protection, but a finding that the court can extinguish such royalties to enhance the saleability of the underlying asset will negate the protections and benefits afforded to interests of this nature and have profound commercial implications. Although a court's discretion to vest off thirdparty property rights would likely be limited to narrow circumstances, such a finding would disregard the express intentions of the granting party and undermine the express policy reasons that informed the Supreme Court of Canada's decision in Dynex. 


\section{POSTSCRIPT}

Following the presentation of this article at the 2019 Canadian Energy Law Foundation Conference, the Ontario Court of Appeal released its much anticipated second decision in Third Eye Capital Corporation v. Ressources Dianor Inc/Dianor Resources Inc with respect to the comeback hearing that took place in September 2018. ${ }^{123}$ The Court concluded that it had the jurisdiction to grant a vesting order with the effect of extinguishing a third party's interest in land in the nature of a GORR; however, it declined to exercise such jurisdiction in the circumstances.

The Court noted that cases addressing the scope of vesting orders in respect of third-party rights were highly dependent on the particular circumstances of each case and the jurisprudence did not set out a "consistently applied framework of analysis to determine whether a vesting order extinguishing interests ought to be granted." 124 To better organize the legal analysis necessary to resolve this inquiry, the Court established a two-factor framework as part of a "rigorous cascade analysis"125 to determine whether an interest in land should be extinguished. Specifically, a court should consider: (1) the nature of the interest in land, and (2) whether the interest holder has consented to the vesting out of their interest either in the insolvency process itself or in agreements reached prior to the insolvency. ${ }^{126}$ Importantly, the framework espoused by the Court is not composed of steps that must each be followed; rather, any one factor may be dispositive. ${ }^{127}$

Regarding the first factor, the Court held that the key inquiry is the nature of the particular interest and the degree to which it forms a part of the underlying estate: is it "more akin to a fixed monetary interest that is attached to real or personal property subject to the sale (such as a mortgage or lien for municipal taxes), or whether the interest is more akin to a fee simple that is in substance an ownership interest in some ascertainable feature of the property itself'? ${ }^{128}$ If the latter, the reasonable expectation of the owner of such an interest would be that its interest was of a continuing nature, and absent consent, could not be involuntarily extinguished in the ordinary course through a payment in lieu thereof. This factor was essential to the Court's analysis of the GORRs at the center of the Dianor litigation. Although the GORRs were not fee simple interests, they were more than fixed monetary interests and did not exist simply to secure a fixed finite monetary obligation. The Court concluded that the GORRs were "in substance an interest in a continuing and inherent feature of the property itself." 129 The Court went on to state that:

While the [GORR], like a fee simple interest, may be capable of being valued at a point in time, this does not transform the substance of the interest into one that is concerned with a fixed monetary sum rather than an element of the property itself. The interest represented by the [GORR] is an ownership in the product of the mining claim, either payable by a share of the physical product or a share of revenues. In other words, the 
[GORR] carves out an overriding entitlement to an amount of the property interest held by the owner of the mining claims. $^{130}$

The second factor to consider is whether the interest holder has consented to its interest being vested off, whether prior to the insolvency or at the time of the sale for which the vesting order is being sought. The Court did not point to evidence of any consent on the part of the GORR holder to its interest being vested off or subordinated, but if it had, it is possible that the GORRs would not have survived the insolvency.

Where the above factors prove to be "ambiguous or inconclusive," a court may then consider the equities to determine if a vesting order is appropriate in the particular circumstances. ${ }^{131}$ Here, given the nature of the GORRs and the absence of any agreement allowing for any competing priority, there was no need to resort to a consideration of the equities.

While, at first blush, the Court of Appeal appears to have widened the door for a court's authority to extinguish a third-party interest using a vesting order in insolvency proceedings, a more practical perspective suggests it is unlikely that many "typical" GORRs in the oil and gas context can be extinguished based on the framework and considerations developed by the Court. Where the GORR is an element of the property itself, it cannot be reduced to an interest concerned with a fixed monetary sum merely because it may be capable of being valued at a point in time. Similar to the GORRs at issue in this case, standard oil and gas GORRs (including those granted under the 2015 CAPL Overriding Royalty Procedure) would also likely be characterized in substance as an interest in a continuing and inherent feature of the property, and therefore fall closer to the fee simple end of the "interest in land spectrum," insulated from a court's exercise of its "vesting off" jurisdiction.

The second part of the framework considers whether the owner of the interest in land might have consented to the vesting off of the interest or subordination of the interest. This, again, would be unusual in the typical grant of a GORR in the oil and gas context. That being said, this is an important consideration for drafters of customized royalty agreements to remain mindful of; subordination of the GORR interest to the interest of existing secured lenders is frequently a negotiated point on significant royalty transactions. Put differently, it is clear from this decision that the priority of interests is paramount, and GORR holders should ensure such priority is reflected in the royalty agreement. Furthermore, there is no subordination to other interests, such as that of a secured lender.

While it seems likely that many standard oil and gas GORRs would be protected from extinguishment under a vesting order on the basis of this framework, if it is still "ambiguous or inconclusive" at the end of the analysis, the court is then to consider the equities, including the prejudice to the royalty holder, whether the royalty holder could be adequately compensated for their interest, and whether there is any evidence of value in the property itself, et cetera, in deciding whether to grant the vesting order extinguishing the third-party interest. 
While the Court of Appeal expressly sought to provide a framework for courts to approach the analysis as to whether or not a vesting order extinguishing a third party's interest is appropriate, it is not entirely clear, aside from consenting to one's interest being vested off, what specifically a court should consider in determining whether it is appropriate to vest off a third party's interest in land. The parameters of the inquiry remain somewhat vague, but given the potentially sweeping implications for holders of interests in land, the authors remain interested to see if Dianor will make its way to the Supreme Court of Canada. It is unfortunate that the practical outcome of the case was governed by the procedural issue before the Court, namely, the particular appeal period that governed the appeal. As the Court concluded that the GORR holder's appeal was out of time, and the appeal was therefore dismissed, there may be limited motivation to seek leave to allow Canada's highest court to weigh in on the interest in land and vesting issues at play in the Dianor decisions. 
[this page is intentionally blank] 